\title{
FACTORS AFFECTING THE RESPONSE OF CLOVER ESTABLISHMENT TO INOCULATION AND PELLETING
}

\author{
W. L. I.OWTHER \\ Invermay Agriculiural Research Centre, MAF, Mosgiel
}

\section{Absfracf}

Results of trials evaluating the effectiveness of different inoculation and pelleting techniques on the establishment of clovers oversown in tussock grassland sites are discussed. These trials were carried out simulating as far as possible the practical applications. Response to inoculation and pelleting varied with environmental conditions (e.g., altitude, soil acidity and vegetative cover), time of sowing, and populations of rhizobia in the soil. On some soils, clover established reasonably Erom inoculated seed, while on some acid soils effective pelleting of inoculated seed was essential. Environmental conditions influenced the standards required for inoculants and pelleted seed. The importance of field testing in addition to laboratory

testing is stressed.

\section{INTRODUCTION}

Correct inoculation and pelleting techniques can markedly increase establishment and hence dry matter production of oversown clover (Lowther and McDonald, 1973; Lowther, 1975b). However, in New Zealand the subiect of inoculation and pelleting has been particularly controversial and recommendations have varied considerably.

A higher standard of inoculants and inoculated-pelleted seed (pelleted seed), is required for oversowing in the tussock grasslands because of the severe environmental conditions that can occur. This paper shows how environmental conditions can influence the establishment response to inoculation and pelleting and how the recommendation for inoculation and pelleting can vary with different sites.

\section{NEED FOR INOCULATION}

Although it has been well documented that inoculation is essential for legume establishment in many New Zealand tussock grassland soils (Cullen and Ludecke, 1966; Lowther and McDonald, 1973), large areas have been developed through the oversowing of uninoculated clover seed (Tothill, 1958). 
A survey of undeveloped tussock grassland soils in Central Otago and the MacKenzie Country has shown that rhizobia capable of nodulating clover are absent from large areas (Lowther, unpublished results). Although clover rhizobia do occur in tussock grassland soils (Ludecke and Leamy, 1972), their distribution is often irregular (e.g., in creek beds, under scattered patches of clover, on stock tracks) and the only areas where satisfactory populatioris of clover rhizobia can be predicted are those where haresfoot trefoil (Trifolium arvense) occurs (Lowther, unpublished results). Therefore, the only areas in Central Otago and the MacKenzie Country where inoculation is not regarded as necessary for legume establishment are those where haresfoot trefoil occurs throughout.

In the situation where rhizobia are present in tussock grassland soils, the majority are relatively efficient at nitrogen fixation with white clover but not with subterranean clover (Mt Barker or Woogenellup) and hence subterranean clover should always be inoculated with an efficient strain of rhizobia.

\section{EFFECT OF PELLETING}

Under oversowing conditions, pelleting of inoculated seed can have two main effects. On soils where $\mathrm{pH}$ is high enough not to affect nodulation adversely, pelleting can increase clover establishment by increasing the survival of rhizobia on the seed both before and after sowing. On acid soils, in addition to assisting the survival of rhizobia on the seed, pelleting can affect the nodulation process by increasing the $\mathrm{pH}$ in the vicinity of the seedling root (Lowther, 1974) and lime pelleting has been shown to replace the requirement for broadcast lime (Lowther, 1975b) .

On soils where acidity is not a problem, effective pelleting usually results in improved establishment and legume dry matter production (Lowther and McDonald, 1973) although the effect on legume yield will probably disappear with time because of the spread of white clover. However, on acid soils pelleting may be essential for clover establishment. Marked pelleting responses on legume dry matter have been recorded 28 months after sowing (Lowther, 1975b).

\section{FACTORS AFFECTING RESPONSE TO INOCULATION AND PELLETING}

The variation in results that can be obtained from inoculation and pelleting treatments oversown on different sites is shown in Table 1. At Wanaka and Tara Mills, some seedlings established 
TABLE 1: RESPONSE TO INOCULATION AND PELLETING AT DIFFERENT SITES

\begin{tabular}{|c|c|c|c|c|}
\hline & \multirow{2}{*}{$\begin{array}{l}\text { Rhizobia/ } \\
\text { Seed at } \\
\text { Sowing }\end{array}$} & \multicolumn{3}{|c|}{$\%$ Seedlings Established* } \\
\hline & & $\begin{array}{l}\text { Wanaka } \\
(p H 5.3)\end{array}$ & $\begin{array}{l}\text { Tara Hills } \\
\text { (pH 5.5) }\end{array}$ & $\begin{array}{c}\text { Rocklands } \\
(p H 4.8)\end{array}$ \\
\hline Not inosulated & - & 3 & 4 & 1 \\
\hline Jnoculated & 43 & 33 & 26 & 1 \\
\hline Inoculated + Pellet A & 430 & 51 & 39 & 13 \\
\hline Inoculated+ Pellet B & 2500 & 72 & 86 & 53 \\
\hline$d_{v 5}$ & & 15 & 13 & 8 \\
\hline
\end{tabular}

*The percentage of seedlings marked at the cotyledon stage that survived: Pellet $\mathrm{A}=$ methyl cellulose/lime pellet

Pellet $\mathrm{B}=$ commercial pellet

from the inoculated treatment. However, pelleting the seed increased establishment and highest establishment was oblained from pellet B. In contrast, clover seedlings failed to establish from inoculated seed on the acid Rocklands site and only a few seedlings established from pellet A. The only reasonable establishment was obtained from pellet $\mathrm{B}$, probably because of the higher numbers of rhizobia on the seed at sowing.

On some sites, the establishment of seedlings can vary markedly depending on whether the seedling is in the open or under vegetative cover (During et al., 1963; Lowther and McDonald, 1973). For example, at Wanaka, Lowther and McDonald (1973) found that, with inoculated seed, only $15 \%$ of seedlings established in the open compared with $46 \%$ under the cover of fern (Table 2). Pelleting increased establishment, both in the open and under cover, but the need for pelleting would be more important in the open because of the low percentage of seedlings establishing from inoculated seed.

TABLE 2: EFFECT OF COVER ON RESPONSE TO INOCULATION AND PELLETING AT WANAKA

(from Lowther and McDonald, 1973)

\begin{tabular}{|c|c|c|c|}
\hline & $\begin{array}{r}\text { Rhizobia/ } \\
\text { Seed at } \\
\text { Sowing }\end{array}$ & $\begin{array}{l}\% \text { Seedlings } \\
\text { In } 0 \text { pen }\end{array}$ & $\begin{array}{l}\text { Established } \\
\text { Under Fern Cover }\end{array}$ \\
\hline$\overline{\text { Nöt inōiulated }}$ & - & 3 & 3 \\
\hline Jnoculated & 43 & 15 & 46 \\
\hline Inoculated + Pellet A & 430 & 25 & 78 \\
\hline $\begin{array}{l}\text { Inoculated + Pellet B } \\
d_{05}\end{array}$ & 2500 & 49 & 13 \\
\hline
\end{tabular}

Pellet $A=$ methyl cellulose/lime pellet

Pellet $\mathrm{B}=$ commercial pellet 
TABLE 3: EFFECT OF SITE ON RESONSE TO INOCULATION LEVEL

\begin{tabular}{lcc}
\hline & $\begin{array}{c}\% \\
\text { Rocklands } \\
(p H \text { 4.9) }\end{array}$ & $\begin{array}{c}\text { Established } \\
\text { Manapouri } \\
(p H \text { 5.3) }\end{array}$ \\
\hline Inoculated at normal rate $(\mathrm{N}) *$ & 1 & 6 \\
Inoculated at 5 times normal $(5 \mathrm{~N})$ & 1 & 15 \\
$\mathrm{~N}+$ gum arabic/lime pellet & 29 & 66 \\
$5 \mathrm{~N}+$ gum arabic/lime pellet & 51 & 56 \\
$\mathrm{~N}+$ methyl cellulose/lime pellet & 3 & 14 \\
5N + methyl cellulose/lime pellet & 19 & 44 \\
$d_{05}$ & 13 & 18 \\
\hline
\end{tabular}

$* \mathrm{~N}=2.3 \times 10^{3}$ rhizobia/seed at inoculation

$5 \mathrm{~N}=9.3 \times 10^{\prime} \cdot$ rhizobia/seed at inoculation

Seed sown 1 day after inoculation

The site can also influence the standard required for both inoculants and pelleted seed. At Manapouri, increasing the inoculation level from normal to 5 times normal (2.3 to 9.3 $\mathrm{X} 10^{3}$ rhizobia/seed) increased establishment from the methyl cellulose/lime pellet but had no effect on the gum arabic/lime pellet (Table 3). In contrast, on the more acid Rocklands site, increasing the inoculation level increased establishment with both methyl cellulose and gum arabic pellets. Therefore, on sites such as Manapouri, increasing the inoculation level is not necessary if the seed is effectively pelleted. However, if seed is not pelleted correctly or if pelleted seed is sown on a site such as Rocklands, increasing the inoculation level can increase establishment.

The site can also markedly influence establishment from commercially pelleted seed (Table 4). Some pellets with very few rhizobia per seed $(C$ and $D)$ gave relatively satisfactory estab-

TABLE 4: EFFECT OF SITE ON RESPONSE TO COMMERCIAL PELLETING

\begin{tabular}{lcccc}
\hline & $\begin{array}{c}\text { Rhizobia/Seed } \\
\text { at Sowing }\end{array}$ & $\begin{array}{c}\text { Rocklands } \\
(p H ~ 4.9)\end{array}$ & $\begin{array}{c}\text { Seedlings Established } \\
\text { Berwick } \\
(p H \text { 4.6) }\end{array}$ & $\begin{array}{c}\text { Tara Hills } \\
(p H \text { 5.6) }\end{array}$ \\
\hline $\begin{array}{l}\text { Inoculated } \\
\text { Pellet A }\end{array}$ & 700 & 6 & -10 & 36 \\
Pellet B & 600 & 28 & 36 & 63 \\
Pellet C & 150 & 19 & 20 & 50 \\
Pellet D & 10 & 0 & 0 & 24 \\
Pellet E & 10 & 6 & 1 & 36 \\
$d_{05}$ & 20 & 4 & 5 & 6 \\
\hline
\end{tabular}


TABLE 5: EFFECT OF ALTITUDE AND TIME OF SOWING ON RESPONSE TO INOCULATION AND PELLETING ב AT TARA HILLS

\begin{tabular}{|c|c|c|c|c|}
\hline & \multicolumn{2}{|c|}{$\begin{array}{cc}\% \text { Seedlings } & \text { Established } \\
650 \mathrm{~m} & 1000 \mathrm{~m} \\
(\mathrm{pH} \mathrm{5.9)} & (\mathrm{pH} 5.6)\end{array}$} & $\begin{array}{c}\% \text { Plo } \\
\text { Clover } \\
650 \mathrm{~m} \\
\text { (pH 5.9) }\end{array}$ & $\begin{array}{l}\text { vered with } \\
\text { 6-8 months } \\
1000 \mathrm{~m} \\
(\mathrm{pH} 5.6)\end{array}$ \\
\hline & & & & \\
\hline Jul. & 1 & 0 & 8 & 3 \\
\hline Aug. & 26 & 6 & 16 & 2 \\
\hline Sep. & 53 & 8 & 45 & 13 \\
\hline Pelleted† & & & & \\
\hline Jul. & 23 & 6 & 68 & 16 \\
\hline Aug. & 58 & 5 & 65 & 18 \\
\hline Sep. & 73 & 50 & 63 & 41 \\
\hline$d_{05}$ & 22 & 8 & 14 & 10 \\
\hline
\end{tabular}

"Seed sown one day after inoculation. Inoculation supplied approximately $2 \times 10^{3}$ rhizobia/seed.

†Gum arabic/lime pelleting

lishment at Tara Hills, but little or no establishment on the acid sites (Rocklands and Berwick). However, other pellets (E) were ineffective on all sites. Results in Table 4 also show the importance of effective pelleting on acid sites where few seedlings establish from inoculated-only seed. It is therefore clear that commercial pellets must be tested in areas where they will be used to ensure that their quality is satisfactory.

Both altitude and time of sowing appeared to influence the response to inoculation and pelleting on a shady face at Tara Hills (Table 5). On the lower altitude site, pelleting was essential with the July sowing. With August and September sowing, seedlings established in the inoculated treatments but pelleting increased establishment. On the higher altitude site, few seedlings established with July or August sowings using either inoculated or pelleted seed. In September, few seedlings established in the inoculated treatment but there was a marked 'response to pelleting. At the end of the first season, benefits from pelleting were apparent at both sites in the percentage of the plot covered with clover.

In New Zealand, rock-phosphate/dolqmite has been used for commercial pelleting of clover seed based on the work of Hastings and Drake (1963) and Taylor and Lloyd (1968). However. in some instances rock-phosphate/dolomite has proved inferior to lime in the establishment of oversown clover (Lowther and McDonald, 1973; Lowther, 1975a). Pellets were prepared with 
TÁBLE 6: EFFECT OF SITE ON RESPONSE TO COATING MATERIALS 
lime, gypsum, thermophos and Gafsa-phosphate/dolomite as coating materials. When sown 4 weeks after preparation all pellets contained similar numbers of rhizobia (1.4 to $\left.2.3 \times 10^{3}\right)$. However, there were marked differences in establishment when oversown on different sites (Table 6) . Lime pelleting gave high establishment on all sites. Apart from gypsum and thermophos pellets at Coronet Peak, there was a consistent trend for gypsum, thermophos and rock-phosphate/dolomite pellets to give lower establishment than lime pellets. It is clear, therefore, that even though some coating materials maintain viable populations of rhizobia they may not be suitable for the establishment of oversown clovers.

This paper has shown how different environmental conditions affect the response to inoculation and pelleting of oversown seed. The importance of inoculation and pelleting techniques becomes more critical as environmental conditions become more severe and hence it is essential that evaluations for quality standards are carried out in relevant areas.

\section{ACKNOWLEDGEMENTS}

L. D. Bennet, K. D. Trainor and Ms H. N. Patrick for laboratory and field assistance.

\section{REFERENCES}

Cullen, N. A.; Ludecke, T. E., 1966. Proc. N.Z. Grassld Ass., 28: 96-104. During, C.; Cullen, N. A.; Mountier, N. S., 1963. N.Z. $I l$ agric. Res., 6: 416-31.

Hastings, A.; Drake, A. D., 1963: NZ. /l Agric., 306: 463-8.

Lowther, W. L., 1974. N.z. Il agric. Res., 17: 317-25.

$$
\begin{aligned}
& \text { 1975a. N.Z. Il exp. Agric., 3: 121-5. } \\
& \text { 1975b. N.Z. ,l gric. Res.. 18: 357-60. }
\end{aligned}
$$

Lowther, W. L.; McDonald, I. R., 1973. N.Z. /l exp. Agric., 1: 175-9.

Ludecke, T. E.; Leamy, M. L., 1972. Tussock Grassld and Mount Land; Inst. Rev., 25: 14-21.

Taylor, G. G.; Lloyd, J. M., 1968. Proc. N.Z. Grassid Ass., 30: 154-63.

Tothill, J. C., 1958. N.z. Jl Agric., 97: 17. 